Portland State University

PDXScholar

Anthropology Faculty Publications and

Presentations

Anthropology

Winter 2007

\title{
Relic Hunting, Archaeology, and Loss of Native American Heritage at The Dalles
}

Virginia L. Butler

Portland State University, virginia@pdx.edu

Follow this and additional works at: https://pdxscholar.library.pdx.edu/anth_fac

Part of the Archaeological Anthropology Commons

Let us know how access to this document benefits you.

\section{Citation Details}

Butler, V. L. (2007). Relic Hunting, Archaeology, and Loss of Native American Heritage at The Dalles. Oregon Historical Quarterly, 108(4), 624-643.

This Article is brought to you for free and open access. It has been accepted for inclusion in Anthropology Faculty Publications and Presentations by an authorized administrator of PDXScholar. Please contact us if we can make this document more accessible: pdxscholar@pdx.edu. 


\section{VIRGINIA L. BUTLER}

\section{Relic Hunting, Archaeology, and Loss of Native American Heritage at The Dalles}

Excavation of Wake Map mound will be resumed this summer by university students who will find their excavation of last year sadly addled by pot hunters disclaimed by the Oregon Archaeological Society... most of the area around it [the mound] are beginning to look as if they had been worked over by a gold dredge... . The Indians don't like it but aren't doing anything about it. "It doesn't look right," said Chief Charley Kahelamat, who lives at the mound. "All those things belong to the Indians."

- Oregonian, March 29, 1953

NINETEENTH CENTURY EXPLORERS marveled at the thousands of Native people from across the Pacific Northwest and northern Great Basin who gathered in The Dalles region each summer to fish, trade, and socialize. Archaeology demonstrates that various aspects of these gatherings have been

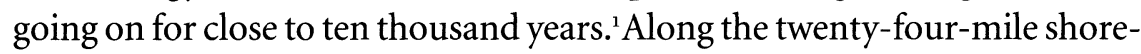
line of The Dalles Dam reservoir in Oregon and Washington, archaeologists have recorded over 120 sites that contain house pits, lithic scatters, elaborately made stone and bone carvings, petroglyphs, and graves. ${ }^{2}$ Native people and non-Native people alike feel strong personal and spiritual connections to this place, in part because it holds such a lengthy record of occupation.

It is important to study the history of how we came to know about that tangible record of the ancient past before activities such as construction of The Dalles Dam seriously degraded it. Relic hunters who took hundreds of thousands of artifacts from the region for curiosity or profit are prominent

This essay is adapted from a talk Virginia L. Butler gave at the "Celilo Stories" conference in The Dalles, Oregon, in March 2007. 


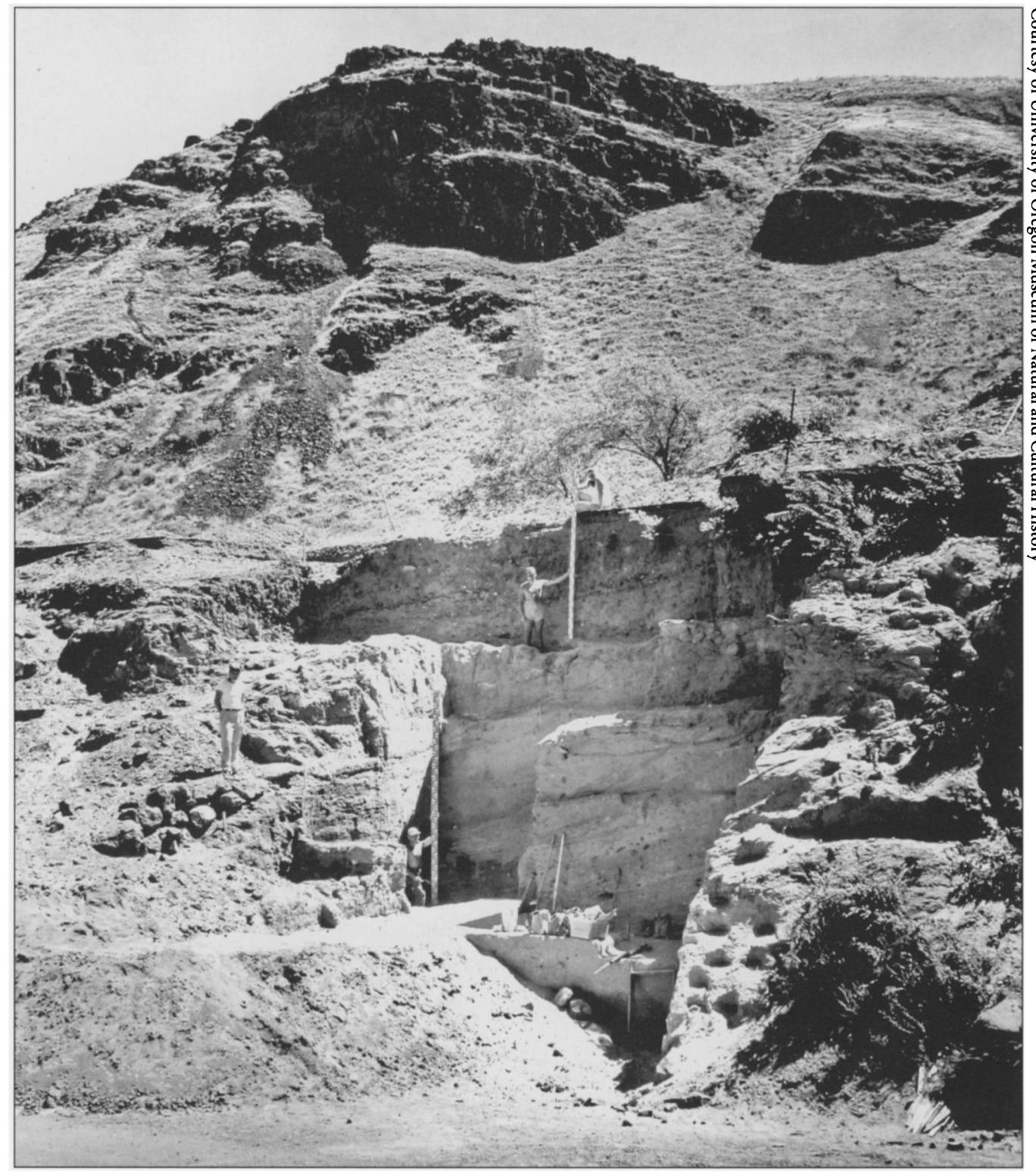

Workers pose at the Fivemile Rapids "Roadcut" site (35WS 8) at the end of the University of Oregon excavation season in 1955. Careful study of artifacts in context demonstrates human occupation between 9300 and 5600 years ago. The deepest layers contained huge quantities of salmon bone, indicating Native people have been salmon fishing in the area for thousands of years. While not heavily looted before dam construction like Wakemap Mound, the site has been seriously disturbed. The top two meters of the about 7.8-meter-thick deposit were destroyed during construction of Highway 30 ; the lowest two meters were inundated when water backed up behind The Dalles Dam. 
in the story, as is their complex relationship with professional archaeologists. Neither group gave much consideration to Indian views about archaeology. This history highlights our national priorities, which promoted hydrodevelopment across the West, yet supplied limited federal dollars to mitigate resulting losses to cultural heritage.

Those past activities caused pain and hurt feelings that are still with us. The court battle over control of the 9400-year-old skeleton, so-called Kennewick Man or the Ancient One, stems in part from a long history of archaeologists and relic hunters treating Indian graves with far less respect than they would give to graves of their own ancestors. Another legacy is the disposition of artifacts looted from The Dalles, most of which are now in private and museum collections and continue to be bought and sold through on-line auctions and other venues.

This paper does not offer any solution or salve for the hurt, but it seeks to tell some of the story, warts and all.

MOST EXCAVATING AND COLLECTING of artifacts on the lower Columbia River before construction of The Dalles Dam was done by relic hunters, hobbyists who were interested in Indian history and who appreciated the thrill of finding old and beautiful things and building personal collections. Some collectors were driven by profit, as there was a market for antiquities through individual buyers and museums. ${ }^{3}$ The Antiquities Act of 1906 made it illegal to excavate or "appropriate" antiquities on federal land, but the law was little enforced and did not much deter collectors. Establishing the scale of the activities - such as the number of items actually taken, the amount of soil screened or dug into, and the number of people who participated - is difficult. Individuals worked on their own and kept limited records, and most collections have become dispersed over time. Anecdotal accounts by collectors and by professional archaeologists who documented plundered sites suggest a level of taking that is almost beyond imagination.

One prominent hobbyist in the first half of the twentieth century was Norma G. Seaman, who in 1946 wrote Indian Relics of the Pacific Northwest, a guidebook for collectors. Seaman directed collectors to The Dalles and hinted at the extent of artifact collecting there:

That part of the Columbia from The Dalles to Celilo is the most interesting part of the river for any kind of Indian study ... great yearly gatherings and the permanent village life naturally enriched the adjoining sandy grounds. The number of relics removed from them can only be guessed at. ${ }^{4}$ 
One of Seaman's associates, Robert Miller, wrote about the huge number of items taken from a locale known as the "Bead Patch":

This is the name given affectionately to a low mound of sand and rock lying ... a few miles east of the city of The Dalles... To compute the number of beads taken from this camp site seems almost a hopeless task. During the eight years ... which I worked there, many people have been "screening." .. Making as careful an estimate as possible from definite knowledge and allowing a fair amount on indefinite reports, I would figure that over 1,00o lineal feet of stone beads have been taken from this camp site during that time, and I believe my estimate is under, not over the actual amount. ${ }^{5}$

Another avid collector was Charles Beckman, known as "Arrowhead Charlie," who made his living buying and selling artifacts taken from along the Columbia River. Beckman was introduced to collecting and to the richness of the artifact record at The Dalles in 1915, when he came to work as a laborer on the Celilo Canal. Between that time and his death in 1947, a friend estimated that Beckman had collected over 150,000 arrowheads. One account suggests he sold 6,500 arrowheads that he had taken between 1930 and 1937 to a collector in New York. Beckman spent three years working at the mouth of the Deschutes River when, as he told a friend, he "would work for about a week when he would have between 800 and 1000 arrowheads, then go to Portland and sell what he had." Clearly, there was a local market for antiquities. Over his thirty-year career, Beckman's takings must have been enormous. ${ }^{6}$

By the mid-1920s, The Dalles region had been extensively scoured by relic hunters. Henry Biddle, an engineer and naturalist from Vancouver, Washington, funded a research team from the University of California, Berkeley, to spend parts of three summers from 1924 through 1926 documenting the archaeological record between The Dalles and Miller Island, as well as on Sauvie Island.7 At the time, professional archaeology in the United States was in its infancy. By 1935, there were only seven Ph.D. programs where students could receive training in archaeological methods and principles, and UC Berkeley's was the only one in the West. ${ }^{8}$ Professional, scholarly archaeologists were mainly concerned with "culture history." Researchers used comparative analysis of "culture traits," such as distinctive artifact style, house type, or burial form, to trace historic Indian groups back in time and over space. ${ }^{9}$ Controlled excavation of material evidence in context was key to deciphering past events; researchers used the relationships of artifacts to each other and their presence in house pits or graves, layers in the ground, or on particular parts of the landscape to establish date of use or cultural group affiliation. 


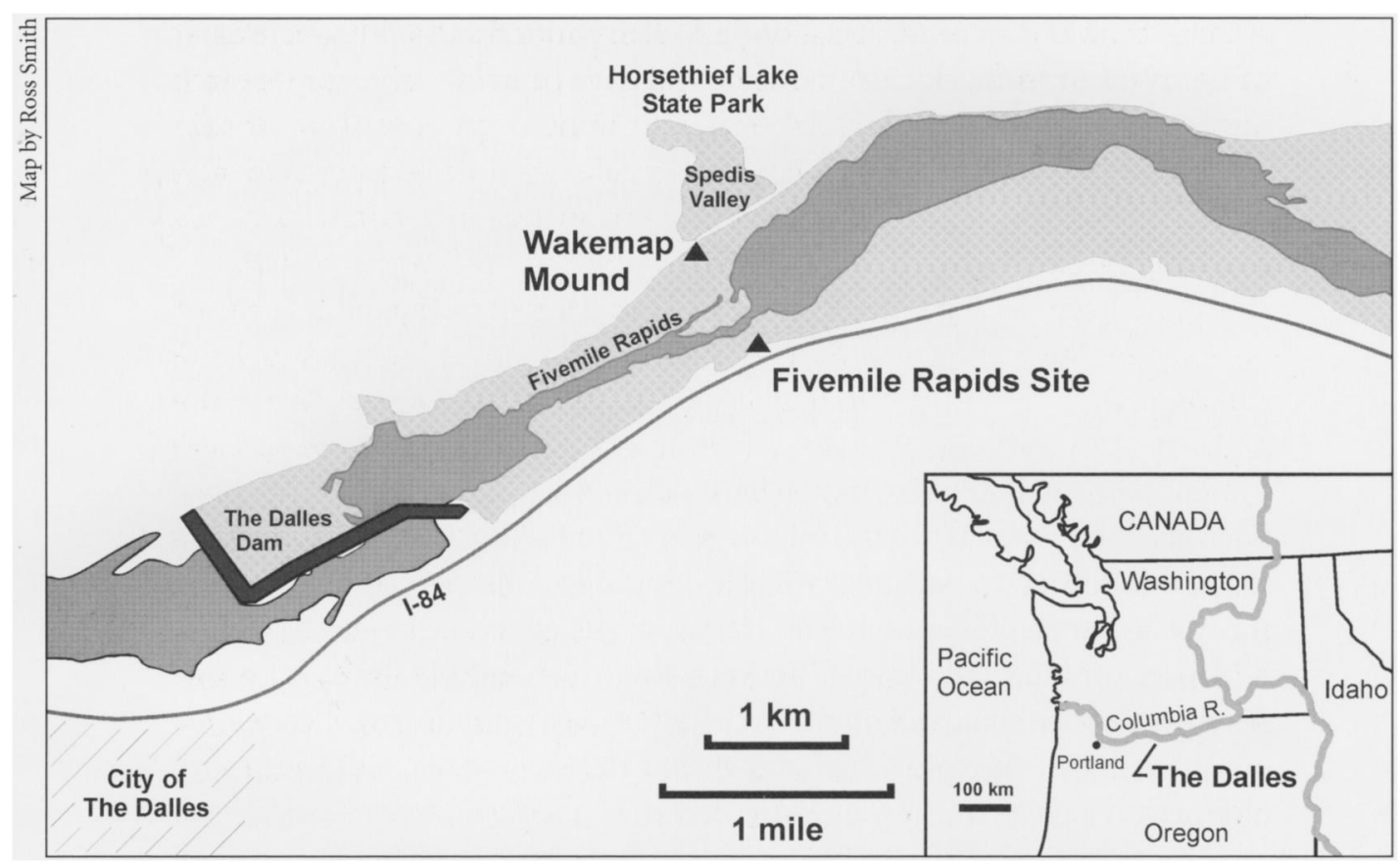

The Fivemile Rapids, or Long Narrows, section of the Columbia River has an extraordinarily rich archaeological record. Both relic hunters and archaeologists focused their activities on the upstream end of the rapids. [Basemap modified from Geo-Recon International, 1983; dark and light shading in river channel indicate water level before and after dam construction.]

The Berkeley team that worked in The Dalles area - W. Duncan Strong, W. Egbert Schenck, and Julian H. Steward - was interested in tracking the mix of peoples from the coast and the arid interior who inhabited the region. To that end, the archaeologists focused their work on large, deep sites that had the greatest potential for abundant artifacts, house remains, and graves in clear stratigraphic context. Two such sites were Wakemap Mound in Spedis Valley, located at the historic Indian village of Wishram on the north side of the head of Fivemile Rapids, and the southern end of Miller Island, across from the mouth of the Deschutes River. ${ }^{10}$

The researchers recorded locations of features such as house remains and of artifacts and used that context along with comparisons of artifact styles known from archaeological studies in California and Washington to infer the origins of cultures at The Dalles and a relative sequence of culture change. Their project is easy to distinguish from the work of relic hunters. Relic hunters seek the artifact, the item, in order to admire it, and they care little about contextual information. Moreover, all of the artifacts and field 
records from the archaeological project were curated at the Phoebe Hearst Museum of Anthropology at Berkeley and have been available for research during the past seventy years, whereas relic hunters generally kept or sold what they found. The UC Berkeley team made multiple references to sites disturbed by haphazard digging. Referring to an area in Spedis Valley with a great concentration of artifacts, Strong and his colleagues noted: "As collectors have been going over this site for years the original number of artifacts left there must have been exceedingly numerous."Discussing a site near Big Eddy, on the Oregon side near the dam site, they wrote: "When the highway, the Celilo Canal, and the O.W.R. \& N. Ry. were put through here in the limited space between the rim rock and the river many artifacts and burials were disclosed.... The artifacts have been much distributed. Some are in public and private collections in Portland..." In referring to perhaps the same site plundered by "Arrowhead Charlie" near the mouth of the Deschutes, the authors stated: "relic hunters have worked this 'placer mine' for a number of years and have recovered, among other things, a very large number of especially fine flint points. For example, in one case over 600 points were taken from a pocket less than $1.2 \mathrm{~m}$. square." ${ }^{11}$

While there were obvious differences between relic hunting and the new profession of archaeology, there were also overlapping interests and areas of mutual support. Strong and his colleagues, for example, thanked collector Dr. G.N. Gannon of The Dalles, who "has been an indefatigable collector of archaeological material from the vicinity and generously placed his experience and his very splendid collection at our disposal." There was certainly a financial link between relic hunters and early professionals; the UC Berkeley project, for example, was funded by Biddle, an active collector. ${ }^{12}$ Collectors and professional archaeologists were also united in their attraction to human burial sites. Professionals valued burials because the types of associated artifacts, construction design (overall form, shape, layout), and condition of the skeleton were useful markers of cultural affiliation. Fifteen of the twenty-two sites W. Duncan Strong and his colleagues described included burials, and much of their commentary refers to the artifacts recovered with those remains. Relic hunters sought burials because the associated artifacts tended to be the most elaborate and complete.

Some professionals were extremely concerned about the pace of site destruction due to relic hunting and wanted to develop stronger laws to protect archaeology. In 1936, Strong and a colleague, F.M. Setzler, published their assessment in the first volume of American Antiquity:

The present actual status of archaeological conservation in the United States... is deplorable.... From motives of mere curiosity or greed, dealers and relic hunters in 


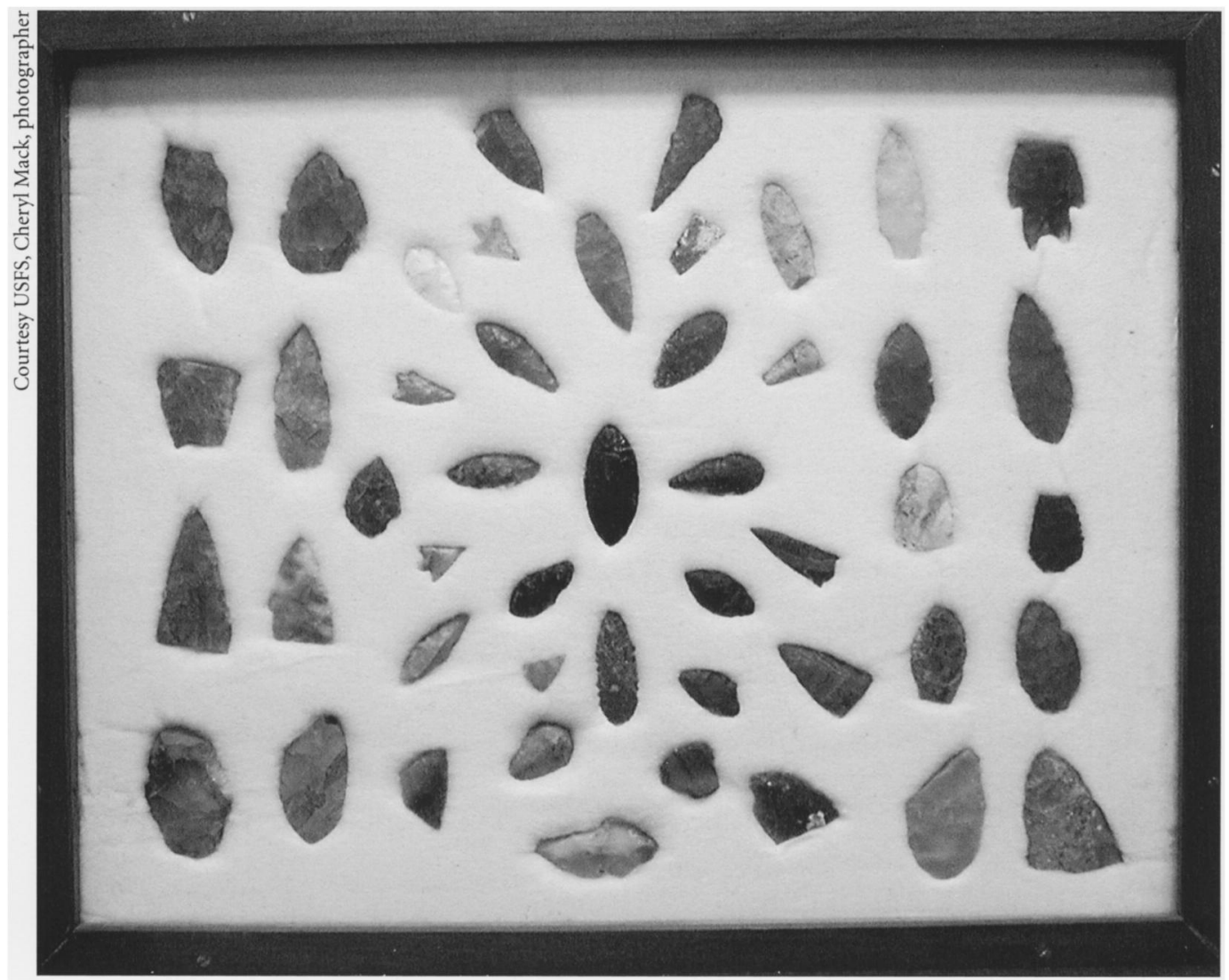

Display cases, such as this one showing Columbia River artifacts collected by a relic hunter, typically include complete artifacts, arranged to highlight their form and color for aesthetic appeal. Relic hunters rapidly dig through sites to collect artifacts and ignore context, which is needed to establish tool function, age, and connection to past lifeways. Site looting also undermines Indian heritage.

practically every state are steadily destroying an irreplaceable heritage... At present a race between the scientist and the curio seeker is on. Scientists are relatively few in number and must work slowly and carefully, whereas relic hunters are extremely numerous, and loot sites with great rapidity. ${ }^{13}$

Despite such differences, when the Society for American Archaeology came into existence in 1934 - the first national organization to promote scientific research in archaeology, public education, and site conservation - it explicitly included amateurs as members. Organizers thought the society would not be economically viable without amateurs, as there were too few professionals. Also, amateurs were able to guide archaeologists to sites and 
to make their collections available for researchers, especially if they were donated to professional institutions. Perhaps to address the concern about site destruction caused by relic hunters, one aspect of the new society's mission was "guiding the research work" of amateurs. ${ }^{14}$

In the decade leading up to construction of The Dalles Dam, the few professionals who worked on the Columbia River took that goal to heart, making efforts to "guide amateurs" in ways that would produce useful scientific products. For the most part, however, amateurs would not be guided or restrained. Professional archaeologists obtained important knowledge and saved records and artifacts from sites lost due to flooding or construction activities, but that knowledge of the past largely came despite the work of amateurs and relic hunters, not because of it.

IN 1945, A FEDERAL INTER-AGENCY program, the River Basin Surveys (RBS), was established to salvage archaeological remains that were to be damaged as a result of federal dam projects. In the years before and after World War II, the U.S. Army Corps of Engineers and the Bureau of Reclamation made plans to construct dams all over the United States. High-level officials in both agencies and professionals in the archaeology community recognized that the threat of nationwide dam construction to historic and prehistoric sites was "enormous and incalculable" and thus developed the RBS to mitigate losses. ${ }^{15}$ The program was run by the Smithsonian Institution, which supplied the archaeological expertise, and the National Park Service, which managed the budget. In many cases, including The Dalles reservoir project, most field research was contracted out to universities. In 1951 and 1952, the RBS funded Joel Shiner of the Smithsonian to conduct a survey and identify sites that would be damaged by early construction activities and by inundation. Shiner suggested that ten sites had some importance, but only three sites received detailed excavation and study. ${ }^{16}$ All were adjacent to Fivemile Rapids. The University of Oregon (under Luther Cressman) was contracted to work on the Oregon side of the river and focused on the Big Eddy site (35 WS 2), located at the dam site, and Fivemile Rapids site (35 WS 8, including localities known as "Roadcut" and "Pit Area"), located on the east end of the rapids. The University of Washington (under Douglas Osborne) focused on Wakemap Mound (45 KL 26). ${ }^{17}$ Some RBS funds were used to record the spectacular petroglyphs on the basalt cliffs adjacent to Wakemap in Spedis Valley. ${ }^{18}$

The amount of federal money allocated for The Dalles archaeological work is not known, but summary budget records suggest the total was small and even nonexistent in some years. Between 1952 and 1956, the RBS spent \$201 thousand for all archaeological work in the country's reservoir 
projects, except in the Missouri Basin. Those funds were spread across 254 reservoirs in twenty-nine states. In 1955, two years before the reservoir was set to fill behind The Dalles Dam, the RBS had zero dollars in its budget for archaeological projects outside the Missouri Basin. ${ }^{19}$

To make up for the limited funds, RBS project managers in The Dalles turned to volunteer laborers, most of whom were amateurs who were extremely concerned about the impending destruction of archaeological sites. $^{20}$ In 1951, an especially active group of fifty-one hobbyists came together to form the Oregon Archaeological Society (OAS). Goals of the organization, as laid out in its Constitution, included:

To preserve in the Northwest for the benefit of science and the public the local archaeological and historical material and traditions that are it's $[s i c]$ heritage ... to cooperate with scientific and academic organizations in the gathering of archaeological data and artifacts ... ${ }^{21}$

These are lofty sentiments that, together with other statements in early society documents, suggest the group of amateurs shared a basic philosophy with professionals - that is, they valued context as much the artifact itself. "The artifact in it's [sic] self should not be the objective," wrote OAS organizers, "but rather the knowledge attained with it's [sic] recovery." Systematic work was promoted, and haphazard digging was criticized. Still, other statements emphasized the traditional relic-hunter philosophy. "Being collectors," the OAS declared, "our main interest is of course searching for artifacts and the enjoyment of the search, but we believe that the enjoyment can be increased by knowledge."Finally, OAS members made it clear they still wanted to personally own what they found: "That which we find is usually ours." ${ }^{22}$

The OAS monthly newsletter, Screenings, indicates the extent of member activity at The Dalles from 1952 to 1957 and illustrates the varying views of archaeology. Sometimes members explicitly worked with professionals to salvage archaeological remains that were to be lost to the dam. A fall 1952 issue reported, for example, that in July, "members [had] dug in an old village site and burial ground near The Dalles under the direction of Louis Caywood [National Park Service] and Joel Shiner [Smithsonian]. Members were shown how to dig for and preserve artifacts." Most articles, however, emphasized the standard relic-hunting credo by showing pictures of artifacts in a member's collection or promoting a digging party. Editors of the same 1952 issue also noted: "Several members have been digging above The Dalles Dam site. ... A large number of gem points were found, sometimes as many as 30 a day, besides the 'ordinary' ones." ${ }^{23}$

The organization and its members were able to reconcile very different approaches to archaeology: systematically excavating, mapping, and 


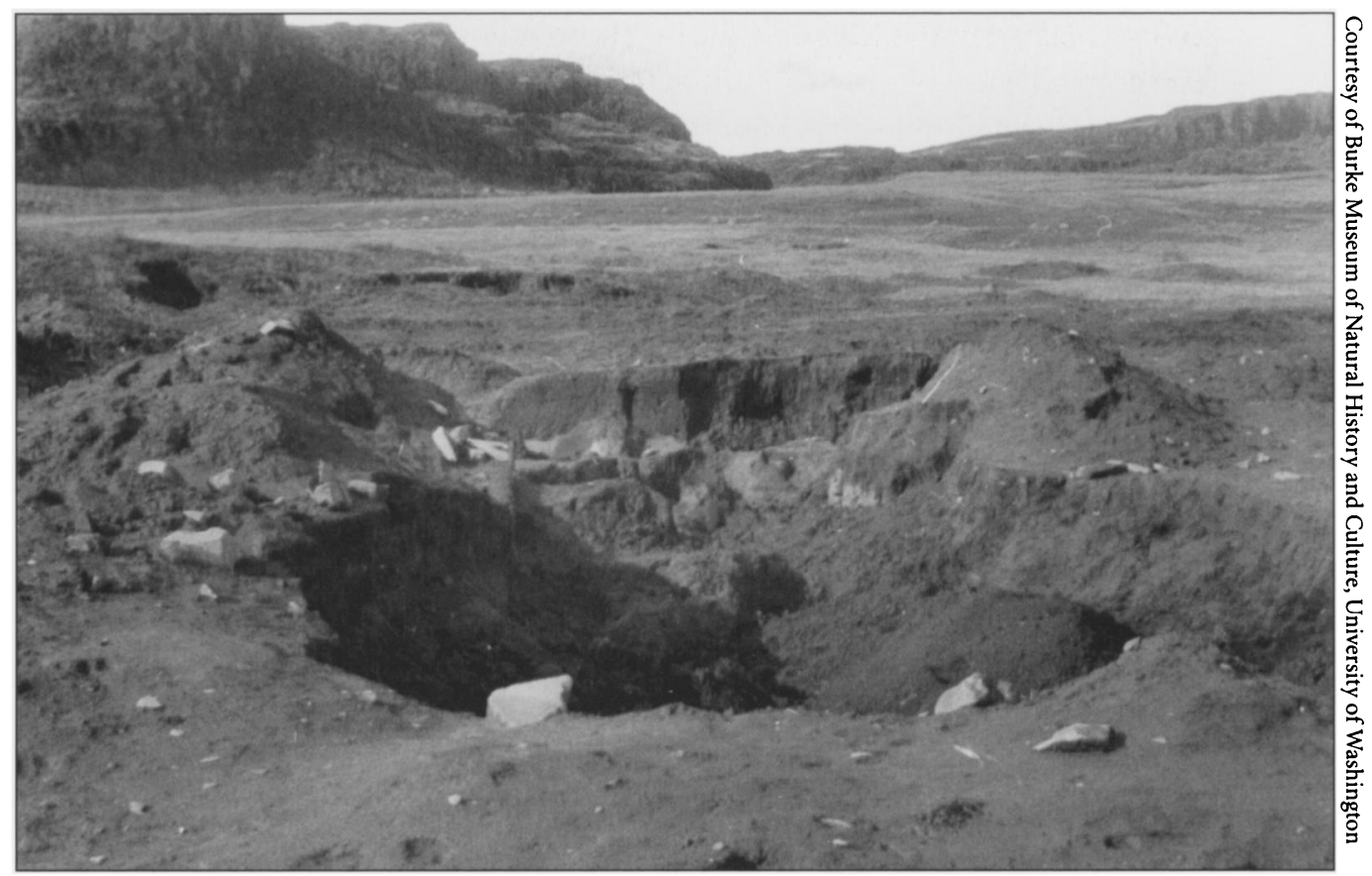

Craters were left by relic hunters at Wakemap Mound (45 KL 26), Spedis Valley, in March 1957. Anecdotal descriptions of relic hunting activity in the months before waters backed up behind the dam conjure images of a feeding frenzy. The location of most of the artifacts taken by relic hunters is unknown.

recording context of artifacts, then returning them to the agency, while also digging and claiming as many interesting items in one day as possible. Apparently, professionals from the University of Oregon, the Smithsonian, and the National Park Service accommodated this seeming contradiction. They worked with OAS members on numerous occasions, submitted articles including notes of praise to the newsletter, and spoke at monthly meetings without any outward sign of conflict or strain. ${ }^{24}$

Nevertheless, events at Wakemap Mound and nearby sites in Spedis Valley exposed some of the contradictions. Professionals essentially gave away parts of the archaeological record to satisfy amateurs' desire to collect and own artifacts. In return, professionals were able to excavate larger sections of sites and to obtain information on artifact context that would have been impossible without volunteers. Still, during this period sites were so overrun by collectors - some OAS members and some unaffiliated — that professionals had difficulty doing their work and facetiously labeled the conflict the "battle of Wakemap." 25 The extent of craters and pockmarks 
from unbridled looting made the area look like a battlefield until floodwaters finally submerged the site.

The mound, built from over two millennia of human occupation, was enormous, approximately 350 feet long, 270 feet wide, and as high as 40 feet. Systematically testing a site that large would be challenging under any conditions, but the limited time and budget exacerbated the difficulty. Salvage archaeology at Wakemap Mound was carried out in two separate projects, both established as the Wakemap Project under Douglas Osborne at the University of Washington. The first field project, conducted in 1953 and 1954, was directed by Warren Caldwell and established some aspects of age and cultural affiliation. The second project, directed by B. Robert Butler from 1955 to 1957 , sought to obtain greater understanding of the layering in the site and to "clarify aspects of the art, architecture and the earliest horizon," work not completed in the earlier study. ${ }^{26}$ Volunteers from OAS helped with both projects, but the relationship became much more formal during Butler's tenure. Butler met with OAS in February 1956, and they agreed on a set of general "principles of cooperation," which included the requirements that volunteers dig in square units and by levels and "that in proportion to what the members of O.A.S. dig for themselves, they shall dig for the University of Washington." ${ }^{27}$ The documented guidelines do not mention whether OAS members would be able to keep artifacts they found. In a March 1956 letter to Osborne, Butler suggested that the National Park Service would not publicly permit such an activity, "but that they probably would not object in view of what we are trying to accomplish." ${ }^{28}$

A more detailed agreement between OAS and the Wakemap Project, established in July 1956, spelled out ownership: “Artifacts found by Oregon Archaeological Society members are to be retained by the Oregon Archaeological Society." The agreement stated that university researchers could retain artifacts for two weeks before they were given to OAS. During that time, the artifacts would be photographed, drawn, and cataloged. According to the agreement, items could be re-examined after the two-week period if more study was needed. The agreement also made OAS the repository for the artifacts and emphasized that artifacts were not to become items of commerce. Artifacts could be exchanged between OAS members or donated to public institutions, but the Wakemap Project needed to be informed of such changes in ownership so that "the whereabouts of Wakemap Mound artifacts of importance may always be a matter of public record." ${ }^{29}$ The agreement was an expedient way for the university project to salvage as much information from the site as possible. Moreover, amateurs and relic hunters were going to hunt for artifacts with or without university cooperation, and the agreement was one way to control some of their taking. ${ }^{30}$ Professionals, 


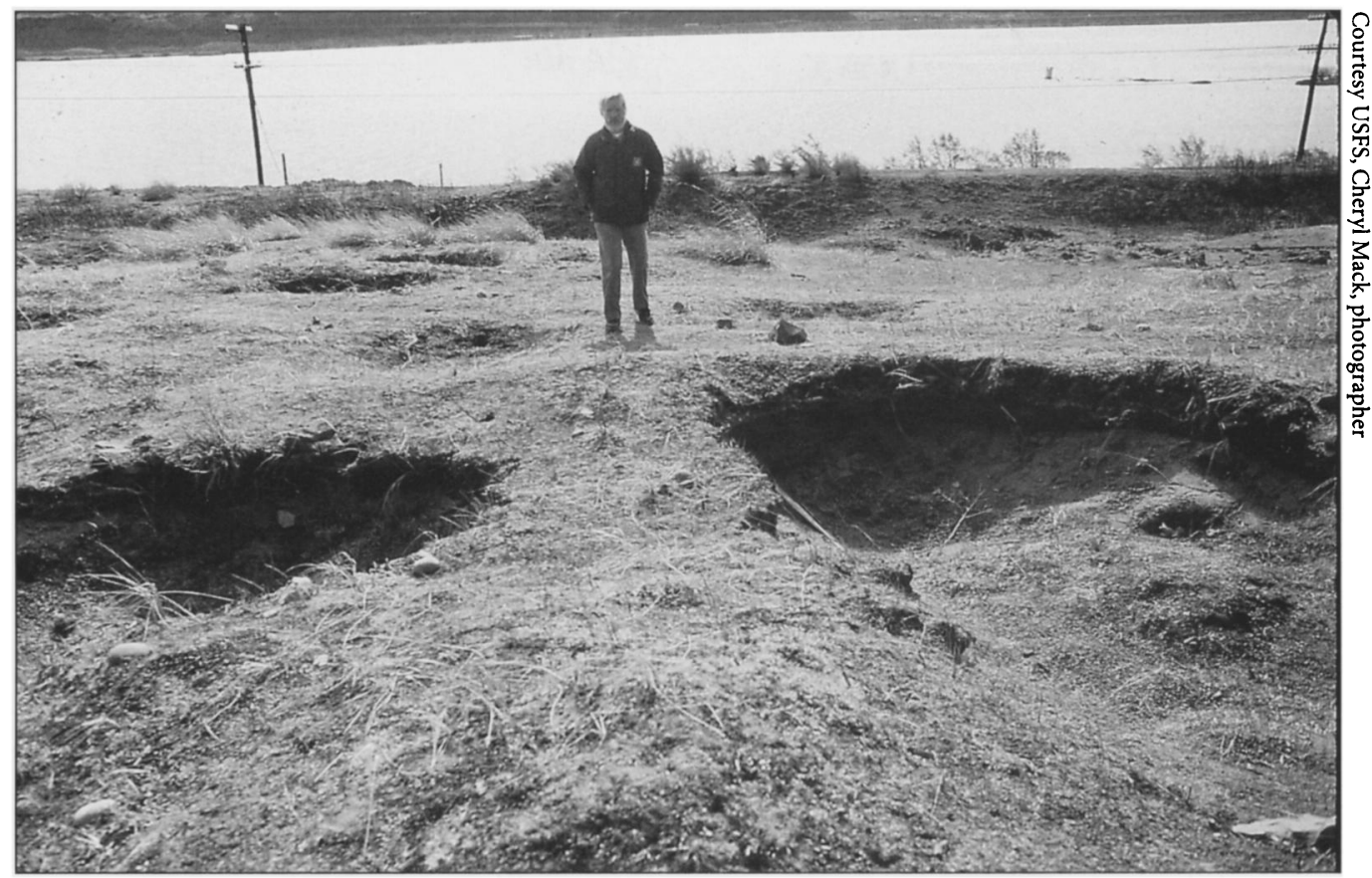

Extensive looting of archaeological sites in The Dalles area occurred before construction of the dam, and the plundering continues, as this 1989 photograph of digging near Wakemap Mound illustrates.

OAS members, and community leaders in The Dalles discussed building a museum in the reservoir area to house and exhibit artifacts from Wakemap and other sites. ${ }^{31}$ That museum would have been a way to retain knowledge about the artifacts and their context in the local area, but the plans never materialized.

The location of only some of the artifacts from the supervised excavation is known. Artifacts from Caldwell's excavations are now curated at the University of Washington's Burke Museum of Natural History and Culture, but only one artifact from Butler's Wakemap excavation was kept there..$^{32}$ The vast majority of items are in private hands. Multiple issues of Screenings between 1955 and 1959 include photographs and descriptions of Wakemap artifacts from OAS members' personal collections; animal effigies, and socalled paint pots and picture rocks are prominent. ${ }^{33}$ The extent to which these collections have entered the antiquities trade is unknown.

Digging by amateurs and relic hunters far surpassed that which occurred during controlled salvage work at Wakemap and surrounding sites. Butler noted, for example, that professional excavation in the Spedis Valley pro- 
duced only six atlatl/throwing spear stone weights, whereas relic hunters collected a hundred. ${ }^{34}$ Perhaps the most egregious example of plundering occurred in April 1956 at the Lois/Over site (45 KL 27) in Spedis Valley, where a D-8 bulldozer with a fifteen-foot wide blade cut four long swaths, one over a hundred feet long, through the site. Butler claimed the people who asked the bulldozer operator to make the cuts were involved in "deliberate, premeditated destruction of that site for the purpose of illegally removing there from $[s i c]$ the antiquities." ${ }^{35}$

Indian people were disturbed by both the plundering and the professionally led projects. In a letter to Douglas Osborne at the University of Washington, Butler repeated the views of Martha Skanawa, an elderly Yakama woman living in Spedis Valley:

Martha has made some rather pointed remarks about the mound and what I am doing. She said: "You make the old woman mad, you make her angry, you kill old woman. When you go away?" - the old woman is Wakemap! ... It would have been a very real pleasure to have accomplished a successful relationship with Martha Skanawa. She absolutely refused further contact between us. I am destroying Waq!mup - I am making her mad. Martha was quite adamant in her speech and quite bitter — and who can blame her? ${ }^{26}$

People appeared to be desperate to get as many artifacts out of the ground as quickly as possible, regardless of the manner of removal. Individuals apparently justified their actions by thinking they were saving artifacts that would be drowned by the reservoir. ${ }^{37}$ Indian people's views on the plundering were little considered. No one seems to have made the case that it would be better to let the sites simply get absorbed by the floodwaters.

CARE AND SENSITIVITY FOR HUMAN remains during the years prior to dam construction were variable. A large number of burials on Upper Memaloose and Grave islands were to be inundated by the reservoir pool, and the U.S. Army Corps of Engineers worked with Indians to disinter the remains and re-bury them in specially designated locations..$^{38}$ In several other instances, amateurs and professionals appeared to have recognized ethical problems with, or at least that Indians were disturbed by, digging in burials; but they went ahead with the activity anyway. One example of amateur grave digging and a subsequent suggestion for making amends was reported in Screenings in 1954:

A slide burial was discovered at Wakemap, not long ago, and after a removal operation which was frantically tho $[s i c]$ not too scientifically carried out by a number of persons, it was noted that the body was in a perfect state of preservation.... Closely associated with the body, in the same cultural strata ... was unearthed a treacherous and very for- 
midable implement resembling a large spear. ... May we suggest, to you who have been working in the vicinity, that, in order to compensate for trespassing and the disturbance we have caused, some sort of small tokens of our appreciation be offered to the Indians in the Wakemap area. Some unwanted article of clothing, a blanket, a box of fruit or candy, or a toy could bring comfort and happiness to these people. ${ }^{39}$

Emory Strong, a leading member of OAS, and author of the 1959 book Stone Age on the Columbia River also held contradictory views on digging at burials. Numerous passages show the extent he and his associates have dug into burials, yet he also remarks on the implications: "There are hundreds of burial grounds, cremation pits, and vault sites along the river, many of which have been excavated for the artifacts. There are probably a great many more that have not been discovered. It is, of course, illegal and unethical to dig a grave." 40

The 1920s UC Berkeley project examined numerous graves in The Dalles area, but referred to Indian views on burials only once: "Judging from the feelings of the present Spedis population and the type and condition of the artifacts, dead have been deposited here in very recent times." ${ }^{41}$ The researchers were aware of Indian concerns about human remains, but appear to have considered them only as a way to estimate the age of the burial, not as a reason to alter professional activity.

Records from the Congdon site (45 KL 41) in Spedis Valley in 1955 show how burial sites were treated in some areas of what would become the reservoir. According to B. Robert Butler,

There were as many as 10-15 amateurs digging in the burial zone at one time, none of whom were acquainted with standard archaeological field techniques and most of whom were more interested in adding to their private collections than in adding to public knowledge of the site. The best that I could do was to bag the skeletal material by lots and briefly note the stratigraphic provenience and associated material. ${ }^{42}$

Remains of fifty-one individuals collected in that way "eventually reached the Washington State Museum." ${ }^{43}$ Of the 20,000 artifacts taken from the site, about one-third were retained for study at the Washington State Museum, about one-third were kept by Dr. Russell Congdon (OAS member and first amateur to actively work the site), and the rest were "scattered among the many relic hunters who ravaged the site." 44

Lack of respect for Indians and their heritage can be viewed as part of discriminatory policies and attitudes that have restricted Native American social and political power since our nation's beginning. ${ }^{45}$ To address one aspect of that injustice, the Native American Graves Protection and Repatriation Act (NAGPRA) was passed in 1990, requiring federal government agencies and 
institutions that receive federal funding to inventory and repatriate human remains and associated funerary items to appropriate tribes. ${ }^{46}$ The law also provides for human remains and associated items found after 1990.

The implications of NAGPRA intersect with the history of archaeology at The Dalles. In June 2007, human remains from the Congdon site near Wakemap were repatriated to a joint group of several tribes - Yakama, Colville, Nez Perce, Umatilla, Warm Springs, and Wanapum. The human remains were re-buried at The Dalles some fifty years after their unceremonious removal. ${ }^{47}$

AS THIS RECENT REPATRIATION OF human remains shows, events that transpired at The Dalles half a century ago are still leaving their imprint. In 2005, the Portland Art Museum mounted a spectacular exhibit, "People of the River, Native Arts of the Oregon Territory," which included over two hundred objects from museum and private collections from the Columbia River. Bone and stone artifacts dating from before Euro-American contact, as well as nineteenth-and early-twentieth-century beadwork, leather crafts, baskets, and wooden masks were displayed. ${ }^{48}$ In introducing the archaeological remains - the exquisitely formed bone, stone, and wood sculpture from the exhibit - curator Bill Mercer notes:

The majority of excavations in the early twentieth century were conducted by amateur archaeologists, and much of what was recovered is scattered throughout private collections.... Also, because the archaeological record is incomplete and precise datings are lacking, many of the objects in this study are identified simply as "pre-contact" rather than being assigned a specific date, which would be nothing more than speculation. ${ }^{49}$

Mercer's phrasing obscures the actual factors and individuals responsible for the loss in knowledge.

The Portland Art Museum show included specific items from the plundered archaeological record from The Dalles - four pieces from Wakemap and one from the Fivemile Rapids site in Oregon. Those five objects and many others are photographed in a 1959 pamphlet that showcased OAS member collections from Wakemap and nearby sites, so one can match objects and site locations. ${ }^{50}$ Yet, the art exhibit and associated book did not include any geographic or site context for the objects, which are simply listed as "pre-contact" from the Columbia River. Leaving out context obscures the manner of recovery, sanitizing what was a messy and haphazard taking, and disconnects the objects from The Dalles and its indigenous peoples, limiting their broader cultural and scientific significance.

The city of Portland and the art museum were right to celebrate the artistic achievements of Columbia River Indians through the exhibit, but it is 


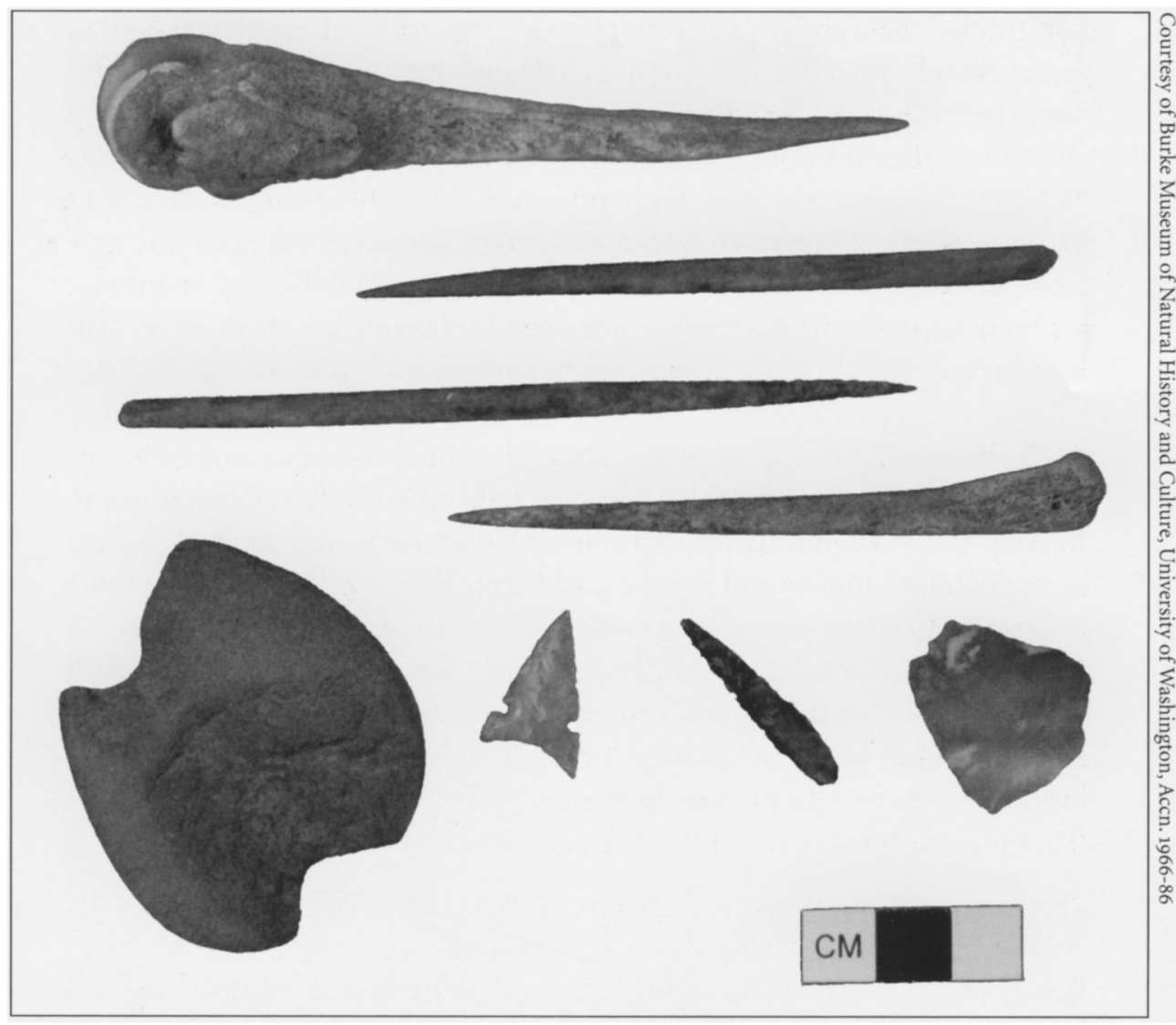

These bone and stone tools from Wakemap Mound were recovered during excavation by University of Washington crews and are curated at the Burke Museum of Natural History and Culture in Seattle, which does not have any artifacts from The Dalles like the stone and bone sculpture shown in the Portland Art Museum exhibit, "People of the River."

important to know how we have come to acquire the tangible records of the past and what was hurt and lost in the scramble to obtain those wonders.

RELIC HUNTERS AND AMATEURS took an enormous share of the artifacts from the ten-thousand-year record of human occupation at The Dalles. Still, organizations like OAS lobbied congressmen and federal agencies for increased funding for archaeology in advance of the dam, and OAS has evolved into an organization that promotes long-term site stewardship and conservation; members only excavate on professionally run projects. ${ }^{51}$ 
Early professionals walked a fine line in actively supporting groups such as OAS while turning a blind eye to the avid-collector trait of its membership. ${ }^{52}$ Today, ethical codes in the Society for American Archaeology explicitly address such issues as site stewardship and commercialization of artifacts, but fifty years ago, the rules were not so clear. ${ }^{53}$ Native Americans' views of archaeology were hardly considered before dam construction. The passage of NAGPRA in 1990 has led to major changes in the way archaeology is practiced in the United States by forcing archaeologists to share control over the past, resulting in more frequent and effective consultation between tribes and archaeologists.

If inanimate things can suffer, the archaeological record at The Dalles surely did in the years before water backed up behind the dam. Unfortunately, the degradation continues as sites along the river are looted for artifacts and as on-line auction sites post items for sale from The Dalles. ${ }^{54}$ To counter these losses, we can refrain from participating in the antiquities trade, work toward stronger laws and enforcement, and educate others that the archaeological past is finite and dying a death from a thousand cuts. Artifact collecting takes from us all, but it is especially destructive to the Native communities whose heritage extends back so many years on the Columbia River.

\section{NOTES}

I gratefully acknowledge help from many people. Ken Ames, Madonna Moss, and Liz Sobel provided very useful comments on the manuscript. Cheryl Mack, Rick McClure (USFS); Ken Karsmizki (Columbia Gorge Discovery Center); Dennis Griffin (Oregon State Historic Preservation Office); Ken Ames (Portland State University); Madonna Moss (University of Oregon); Sarah Campbell (Western Washington University); Michael Martin (USACE); Thomas Thiessen (NPS), Laura Phillips, Stephanie Jolievette, and Kelly Meyers (Burke Museum, University of Washington); Pam Endzweig (Oregon State Museum of Anthropology); and the Oregon Archaeological Society provided copies of unpublished materials or offered ideas and suggestions or both. Cheryl Mack and Laura Phillips provided photographs and Ross Smith drafted the map. Eliza Canty-Jones and other $O H Q$ staff provided excellent editorial and pro- duction assistance. I thank Katrine Barber and other organizers of the "Celilo Stories" conference for asking me to be part of this important event, which forced me to consider the issues laid out here; and I thank Barber, Andy Fisher, and Marianne Keddington-Lang for asking me to contribute to this special issue.

1. Luther Cressman, et. al., Cultural Sequences at The Dalles, Oregon: A Contribution to Pacific Northwest Prehistory, Transactions of the American Philosophical Society, (Philadelphia: American Philosophical Society, 1960), vol. 50, part 10; Warren W. Caldwell, "The Archaeology of Wakemap: A Stratified Site near The Dalles of the Columbia" (PhD. Diss., University of Washington, 1956); Virginia L. Butler and Jim E. O'Connor, "9ooo Years of Salmon Fishing on the Columbia River, North America," Quaternary Research 62 (2004): 1-8; B. Robert 
Butler, "The Physical Stratigraphy of Wakemap Mound: A New Interpretation" (MA thesis, University of Washington, 1960); and Steven Cole, et al., "Rediscovering Wakemap Mound: Archaeology in the Burke Museum" (presentation, Northwest Anthropological Conference, Simon Fraser University, Burnaby, B.C., 1993).

2. Maralee Wernz, et al., "Historic Properties Management Plan for The Dalles Lock and Dam Project" (Portland, Ore: U.S. Army Corps of Engineers, Portland District, 2005); Geo-Recon International, "Cultural Resource Overview and Survey of Select Parcels in The Dalles Reservoir, Oregon and Washington" (Portland, Ore: U.S. Army Corps of Engineers, Portland District, 1983).

3. See David La Vere, Looting Spiro Mounds: An American King Tut's Tomb (Norman: University of Oklahoma Press, 2007), chap. 1; Michael J. O'Brien, Paradigms of the Past: The Story of Missouri Archaeology (Columbia: University of Missouri Press, 1996); and W. Duncan Strong, W. Egbert Schenck, and Julian H. Steward, Archaeology of The Dalles-Deschutes Region, University of California Publications in American Archaeology and Ethnology Volume 29 (Berkeley: University of California-Berkeley, 1930-1932). Only three professional archaeology projects were carried out in The Dalles area before 1950. UC Berkeley's effort, 1924-1926, was the most extensive. Limited field work was done by Alex D. Krieger in 1938 and Luther Cressman in 1936.

4. Norma G. Seaman, Indian Relics of the Pacific Northwest (Portland: Binfords and Mort, 1946), 70.

5. Robert H. Miller, quoted in Seaman, Indian Relics, 8o. Bead Patch site is located near The Dalles Dam.

6. Jay Perry, "Charles Beckman," Screenings 6 (April 8, 1957).

7. Strong, et al., Archaeology of The DallesDeschutes Region, 2.

8. See O'Brien, Paradigms of the Past, 182; $: \rightarrow$ James B. Griffin, "The Formation of the Society of American Archaeology," American Antiquity 50 (1985): 261-71.

9. See R. Lee Lyman, et al., Americanist Culture History: Fundamentals of Time, Space, and Form (New York: Plenum Press, 1997).
10. Wakemap, an anglicized Wishram word meaning 'old woman' or 'ogress,' is pronounced "wok'um'up." See W. Duncan Strong, "Wakemap: A Columbia River site mispronounced," American Antiquity 21 (1956): 410. The large mound, built up from over two thousand years of occupation, was noted by Lewis and Clark on their downriver journey in 1805 . See Henry J. Biddle, "Wishram," Oregon Historical Quarterly 27:1 (March 1926): 113-30.

11. Strong, et al., Archaeology of The DallesDeschutes, 20, 26, 28.

12. Ibid., 2.

13. F.M. Setzler and W. Duncan Strong, "Archaeology and Relief," American Antiquity 1:4 (1936): 308 .

14. Griffin, "The Formation of the Society of American Archaeology," 263, 265.

$\rightarrow$ Jesse D. Jennings, "River Basin Surveys: Origins, Operations, and Results, 1945-1969," American Antiquity 50 (1985): 281-96.

16. Joel L. Shiner, An Appraisal of the Archeological Resources of The Dalles Reservoir on the Columbia River, Oregon and Washington, Columbia Basin Project, River Basin Surveys (Washington D.C.: Smithsonian Institution, 1952).

17. Cressman, et al., Cultural Sequences at The Dalles, Oregon; Caldwell, "The Archaeology of Wakemap"; and Butler, "The Physical Stratigraphy of Wakemap Mound."

18. David L. Cole and J.R. Hegrenes, Jr., "Report on Petroglyphs of The Dalles Reservoir," (San Francisco: National Park Service, Region Four Office, 1953); see also Geo-Recon International, "Cultural Resource Overview and Survey," 35.

19. For River Basin Survey budget information, see Thomas D. Thiessen "Emergency Archeology in the Missouri River Basin: The Role of the Missouri River Basin Project and the Midwest Archeological Center in the Interagency Archeological Salvation Program, 1946-1975," Special Report no. 2 (Lincoln, Neb.: National Park Service, Midwest Archeological Center, 1999), 17. To indicate budget in today's dollars, according to the Consumer Price Index, $\$ 1$ in 1956 is worth $\$ 7.42$ in 2006.

20. Professionals obtained some funds from other sources, including the National 
Science Foundation, the Wasco County-Dalles City Museum Commission, and the University of Washington. See Cressman, et al., Cultural Sequences at The Dalles, Oregon; B. Robert Butler, "The Physical Stratigraphy of Wakemap Mound": and George Poetschat and Harvey Steele, eds., "Formative Years of the Oregon Archaeological Society: Screenings Newsletters 1951 Through 1955," Oregon Archaeological Society Publication no. 10 (1997).

21. Poetschat and Steele, "Constitution of the Oregon Archaeological Society," in "Formative Years."

22. Poetschat and Steele, "Purposes and Objectives," in "Formative Years." See also Screenings 2 (January 1953).

23. Screenings 1:5 (Fall 1952).

24. Professionals who submitted articles to Screenings include Louis Caywood (National Park Service), Joel Shiner (Smithsonian), Luther Cressman (University Oregon), and Robert Stephenson (Smithsonian). Robert Stephenson, Smithsonian Archaeologist, became honorary member of OAS in 1955 and wrote to the organization: "I shall . . . be honored for you to submit my name for honorary membership, I assure you that I will do all in my power to be of utmost service to the group, and I only hope that I can measure up to the high standards and ideals set forth." Screenings 4 (January 10, 1955).

25. American Antiquity 19:3 (January 1954): 311. See also notes about looting in Caldwell, "The Archaeology of Wakemap," 23-25.

26. For more notes about looting, see "Memorandum of Agreement Between the Wakemap Project and The Oregon Archaeological Society," July 29, 1956, archived at Burke Museum of Natural History and Culture, University of Washington.

27. B. Robert Butler to Mr. Jim Hodges, President, OAS, February 23, 1956, Burke Museum of Natural History and Culture, University of Washington, Seattle. See also Screenings 5:3 (March 1956). The correspondence does not mention whether Indian people were consulted during any of this negotiation. Wakemap was situated on property that the U.S. Army Corps of Engineers purchased in 1953; that agency granted the National Park Service (and in turn the University of Washington) permission to excavate. See Steven Cole, et al., "Rediscovering Wakemap Mound: Archaeology in the Burke Museum."

28. B. Robert Butler to Douglas Osborne, March 12, 1956, Burke Museum of Natural History and Culture, University of Washington, Seattle. The Antiquities Act of 1906 made it illegal to remove artifacts from federal land, so Butler knew that NPS would not explicitly approve of such an agreement.

29. Caldwell, "Memorandum of Agreement"; and Geo-Recon International, "Cultural Resource Overview," 38. The number of collected artifacts was too large to adequately document in the two week period, so only a few items were studied in detail. The "whereabouts" of the Wakemap artifacts collected by OAS have never been part of the public record. Even if the society had deemed such information critical, as a volunteer organization without institutional backing and limited funds, it was impractical and overly optimistic to think that OAS would keep track of member collections over decades or longer.

30. See B. Robert Butler interview with F.J. Garavanta, Inv. USACE, April 26, 1956, Burke Museum of Natural History and Culture, University of Washington, Seattle.

31. B. Robert Butler "The Wakemap Project — 'Operation Last Chance' Mazama 37:13 (1955): 35; The Dalles Chronicle, June 9, 1955; and "The 'Dig' at Wakemap," Oregonian March 29, 1953.

32. Personal communication, Stephanie Jolivette, Burke Museum of Natural History and Culture, University of Washington, Seattle.

33. Examples can be found in Screenings 5 (April 9, June 11, 1956).

34. B. Robert Butler, "Lower Columbia Valley Archaeology a Survey and Appraisal of Some Major Archaeological Resources," Tebiwa 2 (1959): 6-24.

35. Butler and F.J. Garavanta interview, 7. According to Butler, relic hunters told a bulldozer operator employed by Morrison-Knudsen that Butler wanted the trenches dug, so the trenches were dug; relic hunters then removed artifacts. Butler, however, did not authorize the 
action and considered the activities vandalism. See also Geo-Recon International, "Cultural Resource Overview," 37-38.

36. This excerpt of Butler's correspondence to Osborne (June 25, and July 4, 1955) is from Steven Cole, et al., "Rediscovering Wakemap Mound: Archaeology in the Burke Museum," 8.

37. Frank Wilke, "Drowned Villages on the Columbia," Screenings 4 (February 11, 1955). Wilke's claim that most of the artifacts saved are in museums is not supported by records from public museums such as the Burke Museum of Natural History and Culture or the University of Oregon Museum of Anthropology.

38. Geo-Recon International, "Cultural Resource Overview," 36.

39. Screenings 3:10 (October 11, 1954).

40. Emory Strong, Stone Age on The Columbia River (Portland: Binfords and Mort, 1959), 86.

41. W. Duncan Strong, et al., Archaeology of The Dalles-Deschutes Region, 19.

42. B. Robert Butler, "Further Notes on the Burials and the Physical Stratigraphy at the Congdon Site, a Multi-Component Middle Period Site at The Dalles on the Lower Columbia River," Tebiwa 69 (1963): 17.

43. Ibid.

44. Butler, "Lower Columbia Valley Archaeology," 9.

45. See various papers in Thomas Biolsi and Larry J. Zimmerman, eds., Indians and Anthropologists (Tucson: University of Arizona Press, 1997). On extensive looting and loss of indigenous heritage at another location in Oregon $\rightarrow$ : Madonna Moss and George B. Wasson, Jr., "Intimate Relations with the Past: the Story of an Athapaskan Village on the Southern Northwest Coast of North America," World Archaeology 29:3 (February 1998): 317-32.

46. Background available online at http:// www.nps.gov/history/nagpra, (accessed August 13, 2007); and David Hurst Thomas, Skull Wars: Kennewick Man, Archaeology, and the Battle for Native American Identity (New York: Basic Books, 2000).

47. Personal communication, Stephanie Jolivette, Burke Museum of Natural History and Culture, University of Washington, Seattle.
48. Bill Mercer, People of the River: Native Arts of the Oregon Territory (Seattle: Portland Art Museum, in association with the University of Washington Press, 2005).

49. Mercer, People of the River, 14.

50. Five objects displayed in People of the River are shown in Emory Strong, Wakemap Mound: a Stratified Site on the Columbia River, 2nd ed. (Portland: Binford and Mort, 1976): Strong, 38, plate 15, "bone implements and art work from Wakemap Mound," is Mercer, 32, catatlog no. 15; Strong 33, plate 12, "ground stone, Wakemap Mound," is Mercer, 47 , catalog no. 34; Strong, 22, plate 6, "steatite fish ornament from Wakemap Mound," is Mercer, 50, catalog no. 38; Strong, 31, Plate no. 11, "stone sculpture mortar from Atlatl Valley," is Mercer, 48, catalog no. 35; and Strong, 31, plate no. 11, "unusual figure from Five Mile Locks," is Mercer, 26, catalog no. 5 .

51. For example, OAS developed the "Save the Petroglyphs" campaign wherein members wrote letters and sent pictures and copies of Screenings to Senators Wayne Morse and Richard Neuberger (Oregon) and Warren G. Magnuson (Washington) for funding to save archaeological sites in the reservoir area. See Screenings 5 (March 12, 1956). For more information on OAS, see their website, http://www. oregonarchaeological.org/index.htm (accessed August 17, 2007); current code of ethics in possession of author.

52. In contrast to other professionals, in multiple papers, $B$. Robert Butler challenged the rampant looting and criticized governmental authorities for not doing enough to protect the archaeological record. See Butler, "The Physical Stratigraphy of Wakemap Mound," 35; and Butler, "The Wakemap Project — 'Operation Last Chance," 35 .

53. For Society for American Archaeology code of ethics, see online document: http:// www.saa.org/aboutSAA/committees/ethics/ principles.html (accessed August 13, 2007).

54. For contemporary examples of archaeological site destruction on the Columbia, see Wernz, et al., "Historic Properties Management Plan," or numerous examples of on-line auction sites. 